\title{
Front Matter: Volume 7865
}

, "Front Matter: Volume 7865," Proc. SPIE 7865, Human Vision and Electronic Imaging XVI, 786501 (24 March 2011); doi: 10.1117/12.888807

EPIE Event: IS\&T/SPIE Electronic Imaging, 2011, San Francisco Airport, California, SPIE. United States 


\title{
PROCEEDINGS \\ IS\&T / SPIE Electronic Imaging \\ SCIENCE AND TECHNOLOGY
}

\section{Human Vision and Electronic Imaging XVI}

\author{
Bernice E. Rogowitz \\ Thrasyvoulos N. Pappas \\ Editors
}

24-27 January 2011

San Francisco, California, United States

Sponsored and Published by

IS\&T-The Society for Imaging Science and Technology

SPIE

Cosponsored by

iPlant Collaborative (United States)

Volume 7865

Proceedings of SPIE, 0277-786X, v. 7865 
The papers included in this volume were part of the technical conference cited on the cover and title page. Papers were selected and subject to review by the editors and conference program committee. Some conference presentations may not be available for publication. The papers published in these proceedings reflect the work and thoughts of the authors and are published herein as submitted. The publisher is not responsible for the validity of the information or for any outcomes resulting from reliance thereon.

Please use the following format to cite material from this book:

Author(s), "Title of Paper," in Human Vision and Electronic Imaging XVI, edited by Bernice E. Rogowitz, Thrasyvoulos N. Pappas, SPIE-IS\&T Electronic Imaging, Vol. 7865 (SPIE, Bellingham, WA, 2011) Article CID Number.

ISSN 0277-786X

ISBN 9780819484024

Copublished by

SPIE

P.O. Box 10, Bellingham, Washington 98227-0010 USA

Telephone +1 3606763290 (Pacific Time) · Fax +1 3606471445

SPIE.org

and

IS\&T-The Society for Imaging Science and Technology

7003 Kilworth Lane, Springfield, Virginia, 22151 USA

Telephone +1 7036429090 (Eastern Time) · Fax +1 7036429094

imaging.org

Copyright ( 2011 , Society of Photo-Optical Instrumentation Engineers and The Society for Imaging Science and Technology

Copying of material in this book for internal or personal use, or for the internal or personal use of specific clients, beyond the fair use provisions granted by the U.S. Copyright Law is authorized by SPIE subject to payment of copying fees. The Transactional Reporting Service base fee for this volume is $\$ 18.00$ per article (or portion thereof), which should be paid directly to the Copyright Clearance Center (CCC), 222 Rosewood Drive, Danvers, MA 01923. Payment may also be made electronically through CCC Online at copyright.com. Other copying for republication, resale, advertising or promotion, or any form of systematic or multiple reproduction of any material in this book is prohibited except with permission in writing from the publisher. The CCC fee code is 0277-786X/11/ \$18.00.

Printed in the United States of America.

Publication of record for individual papers is online in the SPIE Digital Library.

Paper Numbering: Proceedings of SPIE follow an e-First publication model, with papers published first online and then in print and on CD-ROM. Papers are published as they are submitted and meet publication criteria. A unique, consistent, permanent citation identifier (CID) number is assigned to each article at the time of the first publication. Utilization of CIDs allows articles to be fully citable as soon they are published online, and connects the same identifier to all online, print, and electronic versions of the publication. SPIE uses a six-digit CID article numbering system in which:

- The first four digits correspond to the SPIE volume number.

- The last two digits indicate publication order within the volume using a Base 36 numbering system employing both numerals and letters. These two-number sets start with $00,01,02,03,04$, $05,06,07,08,09,0 A, 0 B \ldots 0 Z$, followed by 10-1Z, 20-2Z, etc.

The CID number appears on each page of the manuscript. The complete citation is used on the first page, and an abbreviated version on subsequent pages. Numbers in the index correspond to the last two digits of the six-digit CID number. 


\section{Contents}

vii Conference Committee

KEYNOTE SESSION

786503 How 3D immersive visualization is changing medical diagnostics (Keynote Paper) [7865-02] A. H. J. Koning, Erasmus MC (Netherlands)

786504 Vision as a user interface (Keynote Paper) [7865-03]

J. Koenderink, Delft Univ. of Technology (Netherlands) and Katholieke Univ. Leuven (Belgium)

\section{DESIGN, COMPOSITION, AND ILLUMINATION}

786505 What makes good image composition? [7865-05]

R. Banner, Hewlett-Packard Labs. Israel Ltd. (Israel)

786506 A comparison of perceived lighting characteristics in simulations versus real-life setup [7865-06]

B. Salters, P. Seuntiens, Philips Research Nederland B.V. (Netherlands)

786507 Investigating two features of aesthetic perception in consumer photographic images: clutter and center [7865-07]

C. D. Cerosaletti, A. C. Lovi, A. C. Gallagher, Eastman Kodak Co. (United States)

EXTRACTING, INTEGRATING, AND ANALYZING FEATURES

786508 Analyzing near-infrared images for utility assessment [7865-08]

N. Salamati, Z. Sadeghipoor, S. Süsstrunk, École Polytechnique Fédérale de Lausanne (Switzerland)

786509 Appearance-based human gesture recognition using multimodal features for human computer interaction [7865-09]

D. Luo, Waseda Univ. (Japan) and Karlsruher Institute of Technology (Germany); H. Gao,

H. K. Ekenel, Karlsruher Institute of Technology (Germany); J. Ohya, Waseda Univ. (Japan)

7865 OA Adaptive user interfaces for relating high-level concepts to low-level photographic parameters [7865-10]

E. Scott, P. Madhawa Silva, B. Pardo, T. N. Pappas, Northwestern Univ. (United States)

7865 OB Parametric quality assessment of synthesized textures [7865-11]

D. Siddalinga Swamy, K. J. Butler, D. M. Chandler, Oklahoma State Univ. (United States);

S. S. Hemami, Cornell Univ. (United States)

$78650 \mathrm{C}$ On the perception of band-limited phase distortion in natural scenes [7865-12]

K. P. Vilankar, L. Vasu, D. M. Chandler, Oklahoma State Univ. (United States) 
PERCEPTUAL AND COGNITIVE CHALLENGES IN THE VISUALIZATION AND VISUAL ANALYSIS OF BIOINFORMATICS DATA

7865 OD Applying information visualization principles to biological network displays [7865-13] T. Munzner, Univ. of British Columbia (Canada)

7865 OE Hypergraph visualization and enrichment statistics: how the EGAN paradigm facilitates organic discovery from big data [7865-47]

J. Paquette, T. Tokuyasu, Univ. of California, San Francisco (United States)

7865 OF Perceptual issues in the recovery and visualisation of integrated systems biology data [7865-15]

T. Pridmore, The Univ. of Nottingham (United Kingdom)

7865 OG Using cellular network diagrams to interpret large-scale datasets: past progress and future challenges [7865-16]

P. D. Karp, M. Latendresse, S. Paley, SRI International (United States)

$7865 \mathrm{OH} \quad$ Visualizing large high-throughput datasets based on the cognitive representation of biological pathways [7865-17]

A. Nagel, M. Lohse, A. Bolger, M. Stitt, B. Usadel, Max-Planck-Institut für Molekulare

Pflanzenphysiologie (Germany)

7865 ol Metadata Mapper: a web service for mapping data between independent visual analysis components, guided by perceptual rules [7865-18]

B. E. Rogowitz, The Univ. of Texas at Austin (United States); N. Matasci, Univ. of Arizona

(United States)

EVALUATING THE QUALITY OF THE STEREOSCOPIC EXPERIENCE II: JOINT SESSION WITH CONFERENCE 7863

7865 0J Examination of 3D visual attention in stereoscopic video content [7865-20]

Q. Huynh-Thu, L. Schiatti, Technicolor (France)

7865 OK Quantifying how the combination of blur and disparity affects the perceived depth [7865-21]

J. Wang, M. Barkowsky, V. Ricordel, P. Le Callet, IRCCYN, CNRS, Univ. de Nantes (France)

\section{PERCEPTUAL APPROACHES TO VIDEO QUALITY}

$7865 \mathrm{OL} \quad$ Preferences for the balance between true image detail and noise [7865-22]

S. Deshpande, S. Daly, Sharp Labs. of America, Inc. (United States)

$78650 \mathrm{M}$ Measurement of compression-induced temporal artifacts in subjective and objective video quality assessment [7865-23]

C. Mantel, Gipsa-lab, Grenoble Institute of Technology, CNRS (France) and

STMicroelectronics S.A. (France); P. Ladret, Gipsa-lab, Grenoble Institute of Technology,

CNRS (France); T. Kunlin, STMicroelectronics S.A. (France)

7865 ON Perceived contrast of electronically magnified video [7865-24]

A. M. Haun, R. L. Woods, E. Peli, Schepens Eye Research Institute, Harvard Medical School

(United States) 
$786500 \quad$ Estimating the impact of single and multiple freezes on video quality [7865-25]

S. van Kester, Univ. of Technology Delft (Netherlands); T. Xiao, Acreo AB (Sweden); R. E. Kooij, Univ. of Technology Delft (Netherlands) and TNO (Netherlands); K. Brunnström, Acreo AB (Sweden); O. K. Ahmed, TNO (Netherlands)

7865 OP The effects of scene characteristics, resolution, and compression on the ability to recognize objects in video [7865-26]

J. Dumke, C. G. Ford, I. W. Stange, U.S. Dept. of Commerce (United States)

$7865 \mathrm{OQ}$ Supplemental subjective testing to evaluate the performance of image and video quality estimators [7865-27]

F. M. Ciaramello, Cornell Univ. (United States); A. R. Reibman, AT\&T Labs. Research (United States)

7865 OR On evaluation of video quality metrics: an HDR dataset for computer graphics applications [7865-28]

M. Čadík, T. O. Aydin, K. Myszkowski, H.-P. Seidel, Max-Planck-Institut für Informatik

(Germany)

VISUAL ATTENTION, SALIENCY, AND QUALITY I: JOINT SESSION WITH CONFERENCE 7867

$78650 S \quad$ Interactions of visual attention and quality perception [7865-29]

J. Redi, H. Liu, Technische Univ. Delft (Netherlands); R. Zunino, Univ. degli Studi di Genova (Italy); I. Heynderickx, Technische Univ. Delft (Netherlands) and Philips Research Nederland B.V. (Netherlands)

7865 OT Task dependence of visual attention on compressed videos: point of gaze statistics and analysis [7865-30]

A. Mittal, A. K. Moorthy, W. S. Geisler, A. C. Bovik, The Univ. of Texas at Austin (United States)

$7865 \mathrm{OU}$ Measuring contour degradation in natural image utility assessment: methods and analysis [7865-31]

G. O. Pinto, D. M. Rouse, S. S. Hemami, Cornell Univ. (United States)

VISUAL ATTENTION, SALIENCY, AND QUALITY II: JOINT SESSION WITH CONFERENCE 7867

7865 OV Evolution of attention mechanisms for early visual processing [7865-32]

T. Müller, A. Knoll, Technische Univ. München (Germany)

$7865 \mathrm{OW} \quad$ Learned saliency transformations for gaze guidance [7865-33]

E. Vig, Univ. of Lübeck (Germany); M. Dorr, Univ. of Lübeck (Germany) and Harvard Medical School (United States); E. Barth, Univ. of Lübeck (Germany)

\section{ATTENTION AND GAZE IN CONSTRUCTING THE VISUAL WORLD}

$78650 X \quad$ Relationship between selective visual attention and visual consciousness (Keynote Paper) [7865-34]

N. Tsuchiya, Japan Science and Technology Agency (Japan), RIKEN Brain Science Institute (Japan), and California Institute of Technology (United States); C. Koch, California Institute of Technology (United States) 
7865 OY A gaze-contingent display to study contrast sensitivity under natural viewing conditions [7865-35]

M. Dorr, P. J. Bex, Schepens Eye Research Institute, Harvard Medical School (United States)

$78650 Z$ Analyzing complex gaze behavior in the natural world [7865-36]

J. B. Pelz, T. B. Kinsman, K. M. Evans, Rochester Institute of Technology (United States)

786510 What your visual system sees where you are not looking [7865-37]

R. Rosenholtz, Massachusetts Institute of Technology (United States)

786511 Attention as a Bayesian inference process [7865-38]

S. Chikkerur, Massachussets Institute of Technology (United States); T. Serre, Massachusetts Institute of Technology (United States) and Brown Univ. (United States); C. Tan, T. Poggio,

Massachusetts Institute of Technology (United States)

INTERACTIVE PAPER SESSION

786513 Depth perception enhancement based on chromostereopsis [7865-40]

J. Y. Hong, H. Y. Lee, D. S. Park, C. Y. Kim, Samsung Advanced Institute of Technology (Korea, Republic of)

786514 An evaluation of perceived color break-up on field-sequential color displays [7865-41] M. Kobayashi, A. Yoshida, Y. Yoshida, Sharp Corp. (Japan)

786515 Text detection: effect of size and eccentricity [7865-42]

C.-H. Kao, C.-C. Chen, National Taiwan Univ. (Taiwan)

786516 Image enhancement of high digital magnification for patients with central vision loss [7865-43]

Z. Li, G. Luo, E. Peli, Schepens Eye Research Institute, Harvard Medical School (United States)

786517 Quality versus intelligibility: studying human preferences for American Sign Language video [7865-44]

F. M. Ciaramello, S. S. Hemami, Cornell Univ. (United States)

786518 Metaphor progress report: image recall and blending [7865-45]

H. K. Rising III, Consultant (United States)

786519 Space perception in pictures [7865-46]

A. J. van Doorn, Technische Univ. Delft (Netherlands); J. Wagemans, Katholieke Univ. Leuven (Belgium); H. de Ridder, Technische Univ. Delft (Netherlands); J. J. Koenderink, Katholieke Univ. Leuven (Belgium) and Technische Univ. Delft (Netherlands)

Author Index 


\title{
Conference Committee
}

\author{
Symposium Chair
}

Sabine Süsstrunk, École Polytechnique Fédérale de Lausanne

(Switzerland)

Symposium Cochair

Majid Rabbani, Eastman Kodak Company (United States)

Conference Chairs

Bernice E. Rogowitz, Visual Perspectives Consulting (United States) and The University of Texas at Austin (United States)

Thrasyvoulos N. Pappas, Northwestern University (United States)

Program Committee

Albert J. Ahumada, Jr., NASA Ames Research Center (United States)

Jan P. Allebach, Purdue University (United States)

Erhardt Barth, Universität zu Lübeck (Germany)

Walter R. Bender, MIT Media Laboratory (United States)

Michael H. Brill, Datacolor (United States)

John C. Dalton, Synthetik Software (United States)

Scott J. Daly, Dolby Laboratories, Inc. (United States)

Huib de Ridder, Technische Universiteit Delft (Netherlands)

Elena A. Fedorovskaya, Eastman Kodak Company (United States)

Jennifer Gille, Qualcomm Inc. (United States)

Sheila S. Hemami, Cornell University (United States)

Laurent Itti, The University of Southern California (United States)

Stanley A. Klein, University of California, Berkeley (United States)

Patrick Le Callet, Université de Nantes (France)

John J. McCann, McCann Imaging (United States)

Jeffrey B. Mulligan, NASA Ames Research Center (United States)

Karol Myszkowski, Max-Planck-Institut für Informatik (Germany)

Adar Pelah, The University of York (United Kingdom)

Eliezer Peli, Schepens Eye Research Institute (United States)

Sylvia C. Pont, Technische Universiteit Delft (Netherlands)

Hawley K. Rising III, Consultant (United States)

Sabine E. Süsstrunk, Ecole Polytechnique Fédérale de Lausanne

(Switzerland) 
Christopher W. Tyler, The Smith-Kettlewell Eye Research Institute (United States)

Andrew B. Watson, NASA Ames Research Center (United States)

Session Chairs

1 Keynote Session

Bernice E. Rogowitz, Visual Perspectives Consulting (United States) and The University of Texas at Austin (United States)

Thrasyvoulos N. Pappas, Northwestern University (United States)

2 Design, Composition, and Illumination

Thrasyvoulos N. Pappas, Northwestern University (United States)

3 Extracting, Integrating, and Analyzing Features

Bernice E. Rogowitz, Visual Perspectives Consulting (United States) and The University of Texas at Austin (United States)

4 Perceptual and Cognitive Challenges in the Visualization and Visual Analysis of Bioinformatics Data

Bernice E. Rogowitz, Visual Perspectives Consulting (United States) and The University of Texas at Austin (United States)

5 Evaluating the Quality of the Stereoscopic Experience I: Joint Session with Conference 7863

Eliezer Peli, Schepens Eye Research Institute (United States)

Christopher W. Tyler, The Smith-Kettlewell Eye Research Institute (United States)

Andrew J. Woods, Curtin University (Australia)

6 Evaluating the Quality of the Stereoscopic Experience II: Joint Session with Conference 7863

Eliezer Peli, Schepens Eye Research Institute (United States)

Christopher W. Tyler, The Smith-Kettlewell Eye Research Institute (United States)

Andrew J. Woods, Curtin University (Australia)

$7 \quad$ Perceptual Approaches to Video Quality

Thrasyvoulos N. Pappas, Northwestern University (United States)

8 Visual Attention, Saliency, and Quality I: Joint Session with Conference 7867

Susan P. Farnand, Rochester Institute of Technology (United States)

Bernice E. Rogowitz, Visual Perspectives Consulting (United States) and The University of Texas at Austin (United States)

Thrasyvoulos N. Pappas, Northwestern University (United States) 
9 Visual Attention, Saliency, and Quality II: Joint Session with Conference 7867

Susan P. Farnand, Rochester Institute of Technology (United States)

Bernice E. Rogowitz, Visual Perspectives Consulting (United States) and The University of Texas at Austin (United States)

10 Attention and Gaze in Constructing the Visual World

Elena A. Fedorovskaya, Eastman Kodak Company (United States) 
Downloaded From: https://www.spiedigitallibrary.org/conference-proceedings-of-spie on 26 Apr 2023

Terms of Use: https://www.spiedigitallibrary.org/terms-of-use 